\title{
Author Correction: The role of the SWI/SNF chromatin remodeling complex in maintaining the stemness of glioma initiating cells
}

Hiroaki Hiramatsu ${ }^{1,2}$, Kazuyoshi Kobayashi, ${ }^{1,2}$, Kyousuke Kobayashi' ${ }^{1}$, Takeshi Haraguchi ${ }^{1,2}$, Yasushi Ino $\mathbb{D}^{3}$, Tomoki Todo ${ }^{3}$ \& Hideo Iba ${ }^{1,2}$

Correction to: Scientific Reports https://doi.org/10.1038/s41598-017-00982-3, published online 18 April 2017

This Article contains errors in the Reference list. References 10, 15, 16, 27, 33, 35, 38 and 39 were incorrectly given as:

10. Iba, H. D. \& Brady, W. F. Obtaining credit reports can be risky business. J Clin Orthod 36, 333-335 (2002).

15. Sakurai, K. et al. MicroRNAs miR-199a-5p and -3p target the Brm subunit of SWI/SNF to generate a double-negative feedback loop in a variety of human cancers. Cancer Res 71, 1680-1689, https://doi. org/10.1158/0008-5472.can-10-2345 (2011).

16. Ogata, A. et al. Biaryl modification of the $5^{\prime}$-terminus of one strand of a microRNA duplex induces strand specificity. Bioorg Med Chem Lett 20, 7299-7302, https://doi.org/10.1016/j.bmcl.2010.10.077 (2010).

27. Inayoshi, H. \& Iba, H. Rhythms Emerge in a Collection of 'Blind Chemicals' by the Use of Genetic Switches. Genome Inform Ser Workshop Genome Inform 8, 71-79 (1997).

33. Yamamichi, N. et al. Cdx2 and the Brm-type SWI/SNF complex cooperatively regulate villin expression in gastrointestinal cells. Exp Cell Res 315, 1779-1789, https://doi.org/10.1016/j.yexcr.2009.01.006 (2009).

35. Sugimoto, N. \& Iba, H. Inference of gene regulatory networks by means of dynamic differential Bayesian networks and nonparametric regression. Genome Inform 15, 121-130 (2004).

38. Ui, M. et al. Retrovirus vectors designed for efficient transduction of cytotoxic or cytostatic genes. Gene Ther 6, 1670-1678, https://doi.org/10.1038/sj.gt.3301009 (1999).

39. Yamamichi, N. et al. Locked nucleic acid in situ hybridization analysis of miR-21 expression during colorectal cancer development. Clin Cancer Res 15, 4009-4016, https://doi.org/10.1158/1078-0432.ccr-08-3257 (2009).

The correct references are listed below as references $1-8$.

\section{References}

1. Yaniv, M. Chromatin remodeling: from transcription to cancer. Cancer Genet, https://doi.org/10.1016/j.cancergen.2014.03.006 (2014).

2. Tando, T. et al. Requiem protein links RelB/p52 and the Brm-type SWI/SNF complex in a noncanonicalNF-kappaBpathway. J Biol Chem 285, 21951-21960, https://doi.org/10.1074/jbc.M109.087783 (2010).

${ }^{1}$ Division of Host-Parasite Interaction, Department of Microbiology and Immunology, The Institute of Medical Science, The University of Tokyo, Tokyo, 108-8639, Japan. ²Division of RNA Therapy, Medical Mycology Research Center, Chiba University, Chiba, 260-8673, Japan. ${ }^{3}$ Division of Innovative CancerTherapy, and Department of Surgical Neuro-Oncology, The Institute of Medical Science, The University of Tokyo, Tokyo, 108-8639, Japan. Correspondence and requests for materials should be addressed to H.I. (email: iba@ims.u-tokyo.ac.jp) 
3. Ishizaka, A. et al. Double plant homeodomain (PHD) finger proteins DPF3a and -3b are required as transcriptional co-activators in SWI/SNF complex-dependent activation of NF- $\kappa B$ RelA/p50 heterodimer. J Biol Chem 287, 11924-11933, https://doi.org/10.1074/ jbc.M111.322792 (2012).

4. Yang, P. et al. RCOR2 is a subunit of the LSD1 complex that regulates ESC property and substitutes for SOX2 in reprogramming somatic cells to pluripotency. Stem Cells 29, 791-801, https://doi.org/10.1002/stem.634 (2011).

5. Watanabe, H. et al. SWI/SNF complex is essential for NRSF-mediated suppression of neuronal genes in human nonsmallcell lung carcinoma cell lines. Oncogene 25, 470-479, https://doi.org/10.1038/sj.onc.1209068 (2006).

6. Haraguchi, T., Ozaki, Y. \& Iba, H. Vectors expressing efficient RNA decoys achieve the long-term suppression of specific microRNA activity in mammalian cells. Nucleic Acids Res 37, e43, https://doi.org/10.1093/nar/gkp040 (2009).

7. Haraguchi, T. et al. SiRNAs do not induce RNA-dependent transcriptional silencing of retrovirus in human cells. FEBS Lett 581, 4949-4954, https://doi.org/10.1016/j.febslet.2007.09.028 (2007).

8. Yamamichi, N. et al. The Brmgene suppressed at the post-transcriptional level in various human cell lines is inducible by transient HDAC inhibitor treatment, which exhibits antioncogenicpotential. Oncogene 24, 5471-5481, https://doi.org/10.1038/sj.onc. 1208716 (2005).

(c) (i) Open Access This article is licensed under a Creative Commons Attribution 4.0 International

License, which permits use, sharing, adaptation, distribution and reproduction in any medium or format, as long as you give appropriate credit to the original author(s) and the source, provide a link to the Creative Commons license, and indicate if changes were made. The images or other third party material in this article are included in the article's Creative Commons license, unless indicated otherwise in a credit line to the material. If material is not included in the article's Creative Commons license and your intended use is not permitted by statutory regulation or exceeds the permitted use, you will need to obtain permission directly from the copyright holder. To view a copy of this license, visit http://creativecommons.org/licenses/by/4.0/.

(c) The Author(s) 2018 